\title{
PENYAKIT MASA LAMPAU PADA PENDUDUK CARUBAN MASA KLASIK- ISLAM: SUATU TINJAUAN PALEOPATOLOGI
}

\section{DISEASES IN THE PAST FROM CLASSICAL-ISLAMIC PERIOD COMMUNITY OF CARUBAN: PALEOPATHOLOGICAL PERSPECTIVE}

\author{
Ashwin Prayudi ${ }^{1}$, Rusyad Adi Suriyanto ${ }^{2}$ \\ ${ }^{1}$ Peneliti Independen, ${ }^{2}$ Laboratorium Bioantropologi dan Paleoantropologi, \\ Fakultas Kedokteran, Universitas Gadjah Mada \\ ashwin.prayudi@gmail.com
}

\begin{abstract}
Caruban is a site which emerged between Classical and Islamic period. This site is, located in Lasem District, Rembang Regency, Central Java. In an excavation in 1981, there were three human remains located from this site. This research objective is to find the evidence of diseases from the human remains curated in Laboratory of Bioanthropology and Palaeoanthropology, Gadjah Mada University. This research use paleopathological approach and macrosopic analysis. The results of this research are the individuals age and sex estimation, diseases and its relations with cultural aspects. The cultural influences which reflected in the remains, were dental modification such as dental ablation and dental filing.
\end{abstract}

Keyword : Paleopathology, Caruban, Java.

\begin{abstract}
ABSTRAK
Situs Caruban merupakan situs peralihan antara masa Klasik dan Islam di Jawa (abad 1417 M) yang terletak di Kecamatan Lasem, Kabupaten Rembang, Jawa Tengah. Pada penggalian tahun 1981 ditemukan tiga rangka manusia pada situs ini. Penelitian ini memiliki tujuan untuk mengetahui penyakit masa lampau yang terdapat pada rangka-rangka tersebut dan melihat kaitannya dengan aspek budaya, dengan menggunakan pendekatan paleopatologi. Analisis yang digunakan dalam penelitian ini adalah analisis makroskopis. Hasil penelitian ini adalah jenis kelamin individu, estimasi usia, jenis penyakit dan pengaruh budaya yang terekam pada rangka manusia yang berupa modifikasi gigi yakni ablasi gigi dan pengikiran gigi atau pangur.
\end{abstract}

Kata Kunci : Paleopatologi, Caruban, Jawa.

$\begin{array}{ll}\text { Tanggal Masuk } & : 12 \text { Agustus } 2017 \\ \text { Tanggal Diterima } & : 12 \text { Oktober } 2017\end{array}$ 


\section{PENDAHULUAN}

Pantai Utara Jawa, terutama Jawa Tengah, merupakan lokasi yang memiliki banyak potensi sumberdaya arkeologis, dan beberapa diantaranya memiliki bukti adanya penguburan manusia. Beberapa situs masa prasejarah yang terletak di daerah tersebut, antara lain Plawangan, Leran, Binangun dan Terjan. Salah satu situs di Pantai Utara Jawa Tengah yang memiliki potensi sebagai bahan penelitian arkeologis adalah Situs Caruban.

Situs Caruban terletak pada Dukuh Caruban, Kelurahan Gedongmulyo, Kecamatan Lasem, Jawa Tengah (Lihat Peta 1.). Situs ini terletak 1,5 kilometer di sebelah barat laut Kota Lasem. Luas Dukuh Caruban adalah 14.727 hektar (Nastiti \& Rangkuti, 1988: 8).

Situs ini merupakan situs peralihan dari masa Klasik menuju masa Islam. Hal tersebut dilihat berdasarkan penelitian terhadap sumber sejarah dan bukti-bukti arkeologis yang menunjukkan adanya perdagangan, seperti keberadaan keramik asing dan boneka porselin Barat yang diperkirakan berasal dari abad ke-17 M. Diperkirakan situs ini menjadi berkembang karena kegiatan perekonomian yang terjadi pada abad 14-17 M (Satari, 1985: 494497).

Jika dikaitkan dengan situs penguburan lainnya di Pantai Utara Jawa Tengah, rangka dari Caruban diperkirakan memiliki penanggalan yang berdekatan dengan rangka dari Bancar, Kabupaten Tuban, yang disimpan di Universitas Airlangga, yang berasal dari abad 14-17 M (Sukadana \& Wangania, 1977: 18). Sementara situs lain seperti Plawangan, Leran, Binangun, dan
Terjan merupakan situs dengan penanggalan yang jauh lebih tua.

Penelitian intensif terhadap situs Caruban dilakukan oleh Pusat Penelitian Arkeologi Nasional pada tahun 1979, 1980, 1981, 1983, 1984 dan 1985. Pada ekskavasi tahap ketiga (tahun 1981) ditemukan tiga rangka manusia yang diperkirakan memiliki keterkaitan dengan situs Caruban tersebut. Seluruh rangka ditemukan pada sektor II; Rangka I diangkat pada tanggal 4 Juni 1981, Rangka II diangkat pada tanggal 3 Juni 1981, dan Rangka III diangkat pada tanggal 2 Juni 1981. Penanggalan radiokarbon terhadap rangka - rangka tersebut belum dilakukan, namun berdasarkan temuan yang terdapat di sekitarnya, mereka diperkirakan berasal dari masa yang sama, yaitu abad ke-14 hingga abad ke-17 Masehi, yang merupakan peralihan antara masa Klasik menuju masa Islam (Nastiti \& Rangkuti, 1988: 3).

Penelitian lebih mendalam mengenai Caruban dilakukan oleh Rangkuti (1986) dengan menganalisis pola persebaran artefaknya. Kesimpulan penelitiannya adalah situs Caruban merupakan situs habitasi, yang di dalamnya terdapat kegiatan seharihari (Rangkuti, 1986:133-159).

Analisis lain yang dilakukan terhadap artefak-artefak dari Caruban dilakukan oleh Prijoharijono (1986) dengan menerapkan metode sampling pada artefak-artefak di situs Caruban untuk memperkirakan frekuensi, kepadatan temuan artefak pada situs, luas dan sebaran artefak di permukaan situs Caruban (Prijoharijono, 1986: 160-187).

Penggunaan rangka manusia dari situs Caruban sebagai bahan penelitian telah dilakukan sebelumnya oleh Boedhisampurno (1984) dengan mendeskripsikan 
osteometri, kraniometri dan odontometri dari rangka-rangka tersebut, yang kemudian dibandingkan dengan daerah lain. Selain itu juga dilakukan identifikasi jenis kelamin, yang menghasilkan kesimpulan bahwa Rangka I dan III adalah perempuan, sedangkan Rangka II adalah laki-laki. Selain itu, umur individu ketika meninggal pada Rangka I adalah sekitar 17 tahun, Rangka II adalah 25-30 tahun dan Rangka III adalah sekitar 20 tahun. Sementara itu, informasi mengenai ras yang didapat dari tengkorak dan gigi-geliginya menunjukkan bahwa ketiga individu ini memiliki hubungan dengan ras Mongoloid. Selain itu, pengaruh budaya berupa mutilasi gigi dapat ditemukan pada Rangka II dan III (Boedhisampurno, 1984: 1-13).

$$
\text { Penelitian ulang }
$$

yang

dilakukan saat ini memiliki beberapa perbedaan dengan penelitian tahun 1984. Salah satu fokus penelitian sekarang yaitu membahas mengenai penyakit dan kelainan pada rangkarangka Caruban, yang tidak dibahas dalam penelitian sebelumnya.

Penelitian mengenai penyakit berdasarkan rangka manusia di Indonesia yang berkaitan dengan konteks arkeologi telah dilakukan sebelumnya oleh beberapa orang peneliti Indonesia. Noerwidi (2016) dalam penelitiannya membahas mengenai aspek biokultural sisa-sisa manusia dari situs Liangan, Temanggung, Jawa Tengah. Kesimpulan penelitian yang dilakukan oleh Noerwidi (2016) menyebutkan bahwa individu tersebut adalah perempuan, dengan ras Mongoloid, dan berumur 18-22 tahun ketika meninggal (Noerwidi, 2016: 90-91. Penyakit yang terdapat pada individu ini adalah kalkulus gigi dan karies. Pada giginya dapat terlihat bekas pangur, yang diperkirakan ada hubungannya dengan estetika (Noerwidi, 2016: 8398). Pada penelitian lainnya, Indriati (2006) mendiskusikan mengenai bekas luka pada kranium Homo erectus Ngandong 7 dari masa Pleistosen, yang disebabkan karena faktor kekerasan yang terjadi pada individu tersebut (Indriati, 2006: 290308).

Penelitian mengenai penyakit pada masa lampau di Asia Tenggara sudah dilakukan dalam berbagai topik bahasan, seperti studi kasus penyakit oleh Tayles (2003), Domett \& Buckley (2012), Willis \& Oxenham (2013), Vlok, et al., (2017); penyakit gigi dan hubungannya dengan perpindahan menuju bercocok tanam oleh Tayles et al., (2000); Pietrusewsky \& Douglas, (2001); Oxenham et al., (2006); dan Newton et al (2013); status kesehatan dan demografi oleh Douglas (1996), Labidon (2012), Cekalovic (2014); modifikasi gigi terutama ablasi gigi oleh Nelsen et al., (2001), Domett et al., (2011), Willman et al., (2016); Enamel hipoplasia dan kaitannya dengan kesehatan ibu dan bayi dibahas oleh McDonell dan Oxenham (2014). Walaupun demikian, penelitian mengenai penyakit pada masa lampau di Indonesia masih kurang jumlahnya.

Penelitian ini bertujuan untuk memeriksa penyakit pada masa lampau dari tiga individu dari Situs Caruban. Hasil dari penelitian ini diharapkan dapat memberikan tambahan data untuk penelitian mengenai penyakit pada masa lampau di Indonesia dan pada konteks yang lebih luas di Asia Tenggara.

\section{METODE}

Sumber daya arkeologis yang dipergunakan pada penelitian 
ini adalah tiga rangka manusia dari Situs Caruban yang disimpan di Laboratorium Bioantropologi dan Paleoantropologi, Universitas Gadjah Mada. Penelitian ini bersifat deskriptif analitis dan menggunakan metode analisis makroskopis dan pendekatan paleopatologi.

Definisi paleopatologi adalah ilmu yang mempelajari tentang penyakit-penyakit dan kelainan pada masa lampau berdasarkan sisa-sisa manusia tersebut, dalam hal ini rangka manusia. Tujuan dari paleopatologi adalah untuk merekonstruksi kehidupan pada masa lampau dan melihat interaksi antara penyakit dengan individu yang menderita penyakit tersebut. Selain itu juga melihat pengaruh kebudayaan terhadap rangka manusia tersebut (Roberts dan Manchester, 2005: 1-3)

$$
\text { Keadaan rangka-rangka }
$$

Caruban pada saat ini relatif lengkap dengan beberapa kerusakan yang terjadi setelah individu meninggal dan kerusakan tafonomi. Seluruh rangka berada dalam keadaan yang baik dan utuh. Pada Rangka I, kelengkapan tulang post-cranium mencapai 70 persen, dengan tidak lengkapnya humerus, scapula dan manubrium. Seluruh tulang panjang berada dalam keadaan lengkap sedangkan pada Rangka II mencapai 80 persen dengan tidak adanya scapula dan vertebra thoracicae. Sementara pada Rangka III hanya ditemukan tengkorak dan bagian ekstremitas atas dengan seluruh ekstremitas bawah tidak dapat ditemukan. Tidak ada penjelasan apakah temuan hanya berupa bagian tubuh atas saja atau ekstremitas bawah tidak dapat diangkat.

Proses identifikasi ini akan dilakukan dengan menentukan jenis kelamin dan estimasi umur ketika meninggal. Setelah ditentukan, akan dilihat secara makroskopis mengenai penyakit, kelainan dan pengaruh aktivitas budaya pada individu-individu tersebut.

\section{HASIL PENELITIAN}

Berdasarkan observasi, jenis kelamin individu-individu ini adalah laki-laki pada rangka II dan perempuan pada rangka III. Rangka I tidak dapat ditentukan jenis kelaminnya karena individu tersebut belum dewasa. Estimasi umur ketika meninggal pada rangka I berkisar antara 15-16 tahun, pada rangka II adalah 40 tahun dan pada rangka III adalah 35-40 tahun.

Terdapat beberapa penyakit pada rangka-rangka dari Caruban yaitu penyakit-penyakit gigi (lihat tabel 1 dan 2) seperti karies, atrisi, kalkulus gigi, dental crowding, periodontitis, dan enamel hipoplasia. Selain itu juga terdapat osteopit pada vertebra, ivory osteoma pada tengkorak dan trauma pada metatarsal. Sebagai tambahan, pada Rangka III, terlihat tidak adanya erupsi pada molar ketiga mandibula kanan. Hal ini dapat terjadi karena kelainan genetis (dental agenesis) atau karena impaksi yang merupakan gigi yang terjebak pada gusi dan biasa terjadi pada molar ketiga. Untuk menentukan status impaksi, perlu dilakukan pemeriksaan dengan menggunakan sinar-X terhadap rahang kanan Rangka III. Analisis dengan menggunakan sinar- $X$ juga dapat membantu untuk menentukan apakah terjadi infeksi pada gigi tersebut atau tidak. Penelitian ini hanya menggunakan metode makroskopis dan tidak menggunakan sinar- $X$ sebagai alat bantu analisis. Hal ini karena penggunaan sinar- $X$ dapat 
mengurangi kandungan aDNA (ancient DNA) pada tulang (Immel et al., 2016: 8-9), yang dapat mengganggu jika suatu saat nanti akan dilakukan penelitian mengenai DNA individu-individu dari Caruban.

\section{DISKUSI DAN PEMBAHASAN}

\section{Penentuan Jenis Kelamin}

Penelitian ini memiliki
beberapa penanda yang dipergunakan dalam menentukan jenis kelamin rangka dari Caruban. Pada bagian tengkorak menggunakan protuberantia occipitalis externa, processus mastoideus, margo supraorbitalis, glabella, dan protuberantia mentalis. Pada bagian pelvis menggunakan incisura ischiadica major, arcus subpubicus, dan ramus inferior ossis pubis (White \& Folkens, 2005: 387398).

Berdasarkan penanda yang telah ditetapkan, dapat diambil kesimpulan bahwa jenis kelamin dari Rangka I tidak dapat ditentukan dengan pasti karena individu ini masih belum dapat digolongkan sebagai individu dewasa. Namun diperkirakan jenis kelamin Rangka I adalah perempuan berdasarkan incisura ischiadica major yang nampak melebar, arcus subpubicus yang melebar, dan ramus inferior ossis pubis yang mulai nampak nyata. Pada Rangka II, jenis kelaminnya adalah laki-laki berdasarkan tengkorak dan pelvisnya. Penentuan jenis kelamin pada Rangka III menunjukkan bahwa individu ini adalah perempuan berdasarkan processus mastoideus, margo supraorbitalis, protuberantia occipitalis externa, dan protuberantia mentalis.

\section{Estimasi Usia}

Penentuan usia individu pada penelitian ini menggunakan beberapa metode yaitu atrisi atau bekas pakai pada gigi (Lovejoy, 1985), derajat penutupan sutura yang merupakan persambungan antar tulang pada tengkorak (Meindl \& Lovejoy, 1985), persambungan epifisis (Buikstra dan Ubelaker, 1994, fasies symphysialis (Todd, 1920) dan facies auricularis (Lovejoy et al., 1985).

Hasil dari pengamatan terhadap Rangka I, disimpulkan bahwa individu ini memiliki umur sekitar 15-16 tahun ketika meninggal. Hal ini diamati dari epifisis ulna dan humerus yang belum menyatu, namun tulang panjang telah memiliki panjang mendekati orang dewasa.

Pada Rangka II, umur dari individu ini diperkirakan lebih dari 40 tahun ketika meninggal. Hasil pengamatan ini berbeda dengan hasil dari penelitian sebelumnya yang dilakukan oleh Boedhisampurno yang menyebutkan individu ini berada pada umur 25-30 tahun (Boedhisampurno, 1984: 4). Penentuan umur berdasarkan sutura pada tengkorak yang memberikan kisaran umur 30-40 tahun, adanya osteopit pada patella, sacrum, vertebra cervicalis dan vertebra lumbalis yang menandakan umur individu ini setidaknya telah melewati 40 tahun, dan pola bekas pakai pada gigi menunjukkan kisaran umur antara 35-40 tahun. Penentuan umur berdasarkan facies symphysialis menunjukkan bahwa individu ini berada pada kisaraan umur 35-45 tahun. Sementara itu, berdasarkan facies auricularis individu ini berada pada kisaran 4045 tahun. Berdasarkan keterangan tersebut, dapat disimpulkan bahwa 
individu ini memiliki umur sekitar 40 tahun ketika meninggal.

Umur Rangka III pada penelitian ini berbeda dengan hasil penelitian yang menyimpulkan bahwa individu ini meninggal dengan usia sekitar 20 tahun (Boedhisampurno, 1984: 4). Pada penelitian ini, usia ketika meninggal Rangka III berkisar antara 35-40 tahun. Hal ini berdasarkan penanda bekas pakai pada gigi yang menghasilkan estimasi umur antara 35-40 tahun. Sementara itu estimasi umur berdasarkan sutura menunjukkan bahwa individu ini berumur 45,2 tahun dengan deviasi 9,1 tahun.

\section{Estimasi Tinggi Badan}

Tujuan dari rekonstruksi tinggi badan adalah untuk melakukan rekonstruksi postur tubuh individu agar dapat diperkirakan proses kehidupan individu tersebut. Estimasi tinggi badan individu dilakukan dengan menggunakan metode Trotter \& Gleser (1958) terhadap manusia dengan ras Mongoloid, dan metode untuk individu suku Jawa oleh Bergman \& The (1955) dengan adaptasi pengurangan $2 \mathrm{~cm}$, yang disarankan oleh (Snell, 1949). Tulang yang dipergunakan adalah seluruh tulang panjang, yaitu femur, fibula, tibia, dan humerus.

Tinggi tulang Rangka I diukur menggunakan tulang femur dan tibianya. Berdasarkan metode Trotter dan Glesser, individu ini memiliki tinggi badan sekitar 156,99 $\mathrm{cm} \pm 3,24 \mathrm{~cm}$. Berdasarkan Bergman dan The dapat diperkirakan individu ini memiliki tinggi badan 154,69 cm. Perlu diperhatikan bahwa karena umur individu ini yang tergolong muda, maka ujung epifisis belum bersatu dengan sempurna. Hal ini membuat proses estimasi tinggi badan menjadi kurang akurat. Berdasarkan tebal diafisis tulang panjang, tidak ada perbedaan antara kiri dan kanan. Hal ini menunjukkan bahwa individu ini menggunakan bagian tubuh kiri dan kanannya dengan seimbang. Walaupun demikian, karena umurnya yang masih relatif muda, sangat wajar jika individu ini memiliki tebal diafisis yang relatif sama.

Pada Rangka II, tulang yang dipergunakan adalah femur, fibula, dan humerus kanan. Tinggi badan perkiraan dari Rangka II berdasarkan metode Trotter \& Glesser (1958) adalah 165,308 cm \pm $3,18 \mathrm{~cm}$. Sementara itu, berdasarkan metode Bergman dan The, femur kanan Rangka II menunjukkan individu ini memiliki tinggi badan 163,82 cm. Selain itu, tempat melekatnya otot pada tulang sangat jelas terlihat pada humerus, ulna dan radius. Hal ini menunjukkan bahwa individu ini memiliki tubuh yang kekar. Berdasarkan tebal diafisis dapat disimpulkan bahwa bagian tubuh kiri dan kanan individu ini dipergunakan dengan seimbang. Perbedaan tebal lengan bagian kanan yang hanya berbeda $0,1 \mathrm{~cm}$ lebih banyak pada bagian kanan menunjukkan bahwa tidak terlihat adanya preferensi penggunaan salah satu sisi tubuh dalam kehidupan sehari-hari.

Pada Rangka III, tinggi badan tidak dapat diperkirakan karena tidak ditemukannya tulang panjang pada rangka ini.

\section{Penyakit Pada Rangka}

\section{Osteopit}

\begin{tabular}{lrr}
\multicolumn{2}{c}{ Osteopit atau yang lebih } \\
dikenal dengan & pembibiran, \\
merupakan & suatu & keadaan \\
tumbuhnya tulang pada margin
\end{tabular}


persendian. Hal ini merupakan akibat dari tubuh beradaptasi terhadap beban yang diterima oleh persendian (Roberts \& Manchester, 2005: 135). Semakin tinggi beban yang diterima persendian, semakin besar ukuran osteopit yang dapat muncul (Roberts \& Manchester, 2005: 152). Osteopit ini biasanya merupakan tanda dari proses penuaan (Roberts \& Manchester, 2005: 137).

Osteopit tersebut terdapat pada Rangka II, yaitu pada bagian patella, sacrum, vertebra cervicalis dan vertebra lumbalis. Pada Rangka III osteopit terdapat pada tulang vertebra thoracicae dan tidak pada tulang yang lain. Rangka I tidak memiliki osteopit karena individu ini masih berada pada kisaran umur yang muda.

\section{Karies Gigi}

Karies merupakan penyakit infeksi pada gigi yang merusak struktur gigi, mahkota, atau akar dan dimulai dengan aktivitas mikroba pada permukaan gigi. Penyebab utama karies adalah bakteri Streptococcus mutans atau Lactobacillus acidophilus (Roberts \& Manchester, 2005: 65). Dampak dari karies gigi ini pada beberapa individu tersebut adalah rasa sakit yang akan mengganggu proses mastikasi dan biasanya terlihat pada perubahan penggunaan sisi untuk mengunyah. Karies gigi jika sakit dapat mengganggu aktivitas keseharian dan kualitas kehidupan individu tersebut (Sheiham, 2006: 625-626).

Rangka yang menunjukkan keberadaan karies gigi adalah Rangka II dan Rangka III. Rangka II menunjukkan bahwa pada karies terdapat pada mahkota gigi molar pertama mandibula kanan. Selain itu terdapat karies pada occlusal molar kedua dan ketiga mandibula kiri. Pada Rangka III, karies terlihat pada akar gigi molar kedua mandibula kanan, molar kedua dan ketiga mandibula kiri.

Berdasarkan perbandingan dengan situs lain di Asia Tenggara, terutama Thailand, dari 67 rangka yang ditemukan di Khok Phanom Di, 39 rangka memiliki karies gigi. Ban Lum Khao 19 dari 43 rangka dan Noen U-Loke 13 dari 42 rangka. (Tayles et al., 2000: 74). Jumlah ini menunjukkan bahwa karies merupakan hal yang sering terjadi pada komunitas di Asia Tenggara.

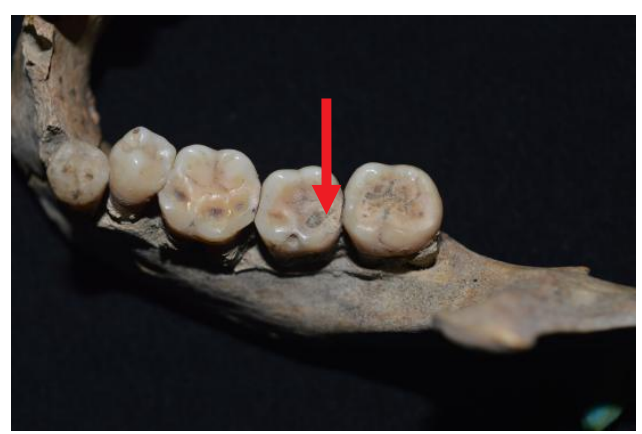

Gambar 1. Karies Gigi Pada Bagian Occlusal Molar Kedua Mandibula Kiri Individu III (Sumber: Dokumentasi Penulis)

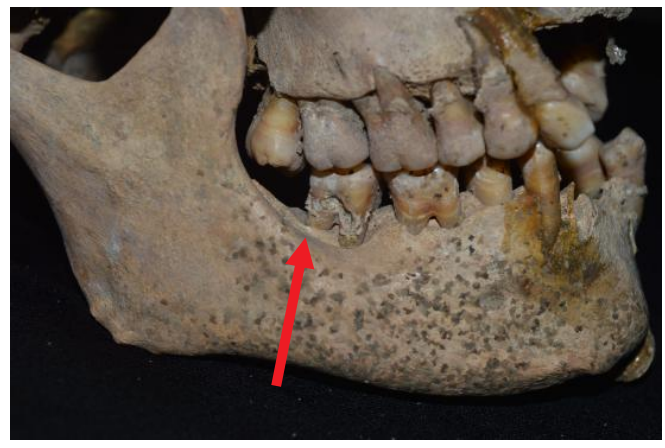

Gambar 2. Karies Pada Akar Gigi Molar Kedua Mandibula Kanan Individu III

(Sumber: Dokumentasi Penulis)

\section{Atrisi Gigi}

Atrisi gigi dikenal pula sebagai bekas pakai gigi. Atrisi gigi merupakan hasil natural yang terjadi pada gigi karena proses mastikasi makanan. Atrisi gigi biasanya terjadi 
pada permukaan occlusal dan tercipta karena proses gesekan dan tumbukan antara gigi mandibula dan gigi maxilla. (Ortner, 2003: 604).

Pada daerah yang berpasir, atrisi gigi dapat menjadi lebih signifikan dari daerah lainnya karena sering tercampurnya makanan dan pasir. Hal tersebut membuat permukaan gigi tergerus oleh pasir. Selain itu makanan pada masa prasejarah Gilimanuk tidak mendapatkan pengolahan dengan cara yang lebih baik jika dibandingkan dengan masa modern. Pada masa prasejarah, makanan akan terasa lebih keras dan lebih sulit untuk dicerna jika dibandingkan dengan makanan pada masa kini. Kerasnya makanan tersebut dapat pula berpengaruh terhadap atrisi gigi (Roberts \& Manchester, 2005: 78).

Lingkungan tempat individuindividu Caruban dikuburkan merupakan tanah yang bercampur dengan pasir. Namun tidak terlihat adanya tanda-tanda abrasi gigi yang normal terjadi pada individu yang tinggal di daerah pantai.

Pada rangka-rangka yang terdapat di Caruban, atrisi gigi terlihat seimbang antara gigi sebelah kiri dan kanan. Hal ini menunjukkan bahwa seluruh individu ini menggunakan kedua sisi giginya untuk proses mastikasi. Selain itu, karena ada keterkaitan antara umur dengan atrisi gigi, maka atrisi gigi lebih terlihat pada individu yang memiliki umur lebih tua dibandingkan yang lebih muda.

\section{Kalkulus Gigi}

Kalkulus gigi adalah mineralisasi dari plak gigi, yang merupakan kumpulan matriks dari mikroorganisme yang berada di gigi. Proses pertumbuhan kalkulus gigi akan semakin cepat jika individu tersebut memakan diet tinggi protein dan/atau tinggi karbohidrat, dan dengan kondisi mulut yang memiliki keasaman tinggi (Roberts \& Manchester, 2005: 71).

Kalkulus gigi dibagi menjadi dua berdasarkan lokasinya yaitu supra-gingival dan sub-gingival. Supra-gingival merupakan kalkulus yang terletak di atas gusi. Kalkulus ini merupakan jenis yang lebih umum, tebal, berwarna cokelat atau abu-abu. Sementara sub-gingival terletak di bawah batas gusi, sering terlihat pada akar gigi yang tersingkap, keras, dan berwarna hijau atau hitam (Roberts \& Manchester, 2005: 72).

Kalkulus gigi dapat dipergunakan sebagai bahan untuk mengetahui jenis diet yang dimakan oleh individu tersebut. Walaupun demikian, penelitian ini tidak akan dilakukan hingga tahap tersebut.

Rangka yang memiliki kalkulus gigi adalah Rangka II dan III. Pada Rangka II, terdapat supragingival kalkulus pada molar pertama dan kedua maxilla sebelah kiri, incisivus pertama dan kedua, caninus, premolar pertama dan kedua mandibula kanan. Kemudian incisivus pertama dan kedua, caninus, premolar pertama, molar pertama, kedua dan ketiga mandibula sebelah kiri.

Pada Rangka III, terdapat sub-gingival kalkulus pada caninus, premolar pertama dan kedua, molar pertama dan kedua maxilla sebelah kanan. Selain itu terdapat pula pada premolar kedua, molar pertama maxilla kiri. Pada mandibula kiri terdapat pada premolar pertama dan kedua, dan seluruh molar mandibula kiri. Pada rangka ini juga terdapat supra-gingival kalkulus pada premolar kedua maxilla kiri dan kanan, molar pertama maxilla kiri dan kanan. 
Pada perbandingan dengan situs lain di Asia Tenggara, kalkulus gigi terdapat pada individu dari Guar Kepah dan Gua Cha di Malaysia dengan tingkat persentase mencapai lebih dari setengah populasi di Guar Kepah dan Gua Cha (Bulbeck, 2005: 395).

Terdapat kemungkinan karena kalkulus gigi tidak menimbulkan rasa sakit, maka individu Caruban tidak mempedulikan keberadaan kalkulus gigi. Hal ini kemudian dapat berujung kepada kurangnya tingkat kepedulian dan pengetahuan untuk membersihkan gigi.

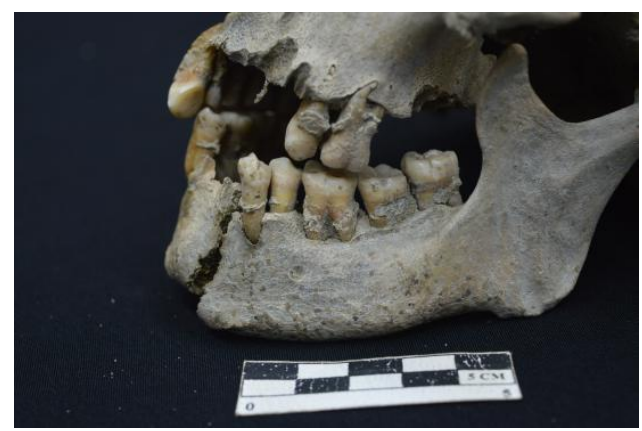

Gambar 3. Kalkulus Gigi Sub dan Supragingival Pada Rahang Individu III (Sumber: Dokumentasi Penulis)

\section{Dental Crowding}

Dental crowding merupakan suatu keadaan di mana gigi yang berada pada mandibula atau maxilla berada dalam keadaan terdesak dari tempat seharusnya sehingga bergeser. Hal ini biasanya terjadi ketika ukuran gigi melebihi ukuran rahang. Penyebab dari keadaan ini masih belum dapat dipastikan (Ortner, 2003: 598), namun pengaruh dari perkembangan pertanian dapat terasosiasi dengan reduksi ukuran gigi, crowding, bertambahnya karies gigi dan periodontitis (Latham, 2013: 96).

$$
\text { Dental crowding telah }
$$

terdapat sejak masa prasejarah dan bukan merupakan permasalahan gigi modern. Masalah ini juga terdapat pada rangka yang berasal dari masyarakat di barat daya Asia dengan penanggalan sekitar 12 ribu tahun yang lalu (Pinhasi et al., 2015: 1-17). Pada kesimpulannya, dental crowding sebagai salah satu penyakit gigi, merupakan penyebab maloklusi gigi pada saat itu.

Dental crowding terdapat pada Rangka II yang terlihat pada gigi caninus mandibula sebelah kanan. Pada pengamatan terhadap rahang Rangka II, dental crowding tidak mempengaruhi proses mastikasi dan tidak mengganggu kehidupan individu tersebut. Hal ini menarik karena walaupun tidak mempengaruhi kehidupan individu tersebut, namun di Indonesia, dental crowding tidak pernah dibahas dalam konteks arkeologi.

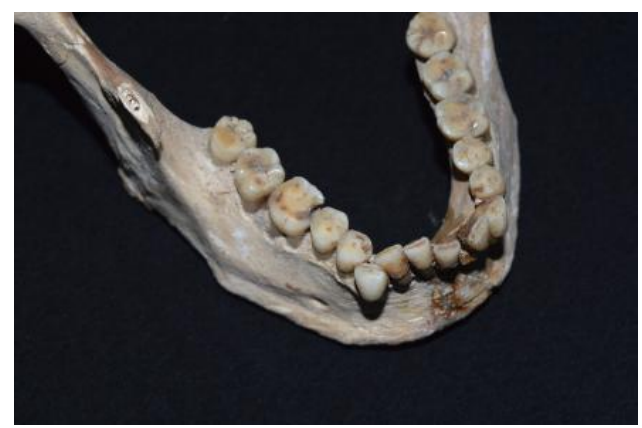

Gambar 4. Dental Crowding Pada Individu II (Sumber: Dokumentasi Penulis)

\section{Periodontitis}

Gingivitis atau yang lebih dikenal dengan gusi berdarah merupakan pembengkakan gusi yang merupakan jaringan lunak dan biasanya terjadi pada daerah perbatasan gusi dengan gigi, yaitu diantara mahkota gigi dan akar gigi. Pada umumnya, hal ini terjadi karena adanya plak gigi. Gingivitis akan berubah menjadi periodontitis ketika didiamkan. Pada kasus yang parah, gingivitis ini dapat berakibat kepada tanggalnya gigi (Ortner, 2003: 593). 
Periodontitis merupakan suatu keadaan di mana tulang alveolar dan ligamen periodontal menghilang yang memperlemah struktur penyokong gigi (Ortner, 2003: 593). Hal ini muncul di antara gigi, jaringan lunak (gusi) dan tulang rahang, dan terjadi karena adanya kalkulus gigi pada daerah tersebut.

Periodontitis merupakan penyakit gigi yang umum pada masa kini dan merupakan salah satu penyebab tanggalnya gigi (Roberts \& Manchester, 2005:73) Pada rangka manusia, hal ini dilihat dari adanya jarak antara tulang alveolar dengan mahkota gigi yang lebih tinggi dari biasanya.

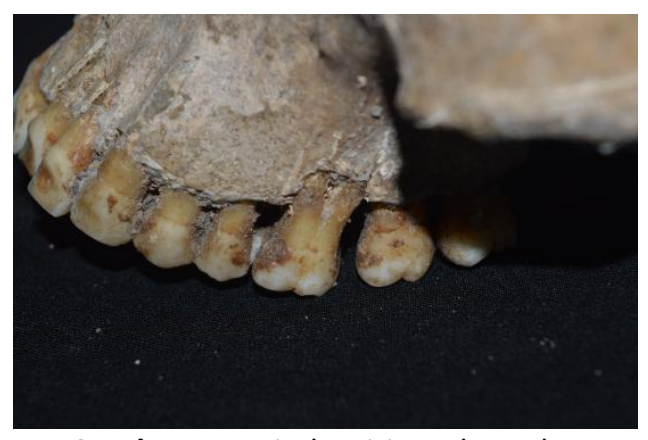

Gambar 5. Periodontitis Pada Molar Pertama Maxilla Kiri Individu II (Sumber: Dokumentasi Penulis)

Periodontitis pada Rangka II terdapat pada molar pertama maxilla kiri, sedangkan pada Rangka III terdapat pada molar ketiga mandibula kiri. Diperkirakan kedua individu ini memiliki penyakit tersebut karena memiliki kalkulus gigi tingkat lanjut yang kemudian menjadi periodontitis. Periodontitis dapat menyebabkan rasa sakit yang akan mempengaruhi kehidupan keseharian individu tersebut.

\section{Enamel Hipoplasia}

Enamel

hipoplasia

merupakan kondisi di mana kualitas gigi yang rendah berakibat pada dentin dan enamel. Cacat yang terjadi pada enamel berupa garis, lubang-lubang kecil atau lekukan pada permukaan enamel yang biasanya terdapat pada incisivus dan caninus (Roberts \& Manchester, 2005: 75). Enamel hipoplasia bisa dikaitkan dengan beberapa penyakit seperti sifilis, rakhitis, tuberculosis, trauma dan kekurangan gizi (Ortner, 2003: 594). Pada penelitian arkeologi, enamel hipoplasia lebih sering dikaitkan kepada gangguan pada pertumbuhan fisik (Hillson, 1996). Hal ini biasanya terjadi sebelum umur 6 tahun karena saat itu merupakan umur ketika mahkota gigi permanen terbentuk (Regezi et al., 2000: 151). Pada penelitian ini, enamel hipoplasia lebih dikaitkan kepada faktor kurangnya gizi pada waktu individu-individu ini sedang berkembang karena tidak terdapat tanda-tanda penyakit yang dapat menyebabkan enamel hipoplasia.

Pada individu dari Caruban, enamel hipoplasia terdapat pada gigi caninus maxilla kanan Rangka III. Pada individu tersebut, garis kerusakan yang terdapat pada hanya berupa satu alur tipis yang melintang.

Pada perbandingannya dengan situs lain di Asia Tenggara, enamel hipoplasia terdapat pada individu yang ditemukan di situs lainnya, yaitu di Gua Cha dan Guar Kepah Malaysia (Bulbeck, 2005). Jumlah individu dengan enamel hipoplasia dari kedua situs tersebut pada gigi caninus adalah 32 dari 51 individu di Gua Cha dan 7 dari 28 individu dari Guar Kepah (Bulbeck, 2005: 396-398). 


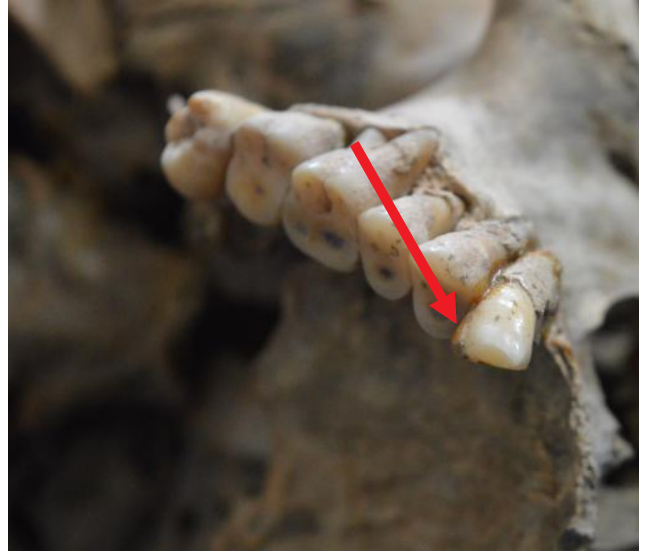

Gambar 6. Enamel Hipoplasia Pada Individu III

(Sumber: Dokumentasi Penulis)

\section{Ivory osteoma}

Ivory osteoma merupakan tumor jinak yang biasanya terletak pada bagian ektokranial tengkorak. Tumor ini biasanya memiliki ukuran lebih kecil dari $1 \mathrm{~cm}$, soliter, padat dan dapat terlihat batas pinggir tumor tersebut (Ortner, 2003: 516). Tumor ini tidak menimbulkan rasa sakit dan gangguan terhadap kehidupan individu yang memilikinya. Bahkan mustahil untuk dapat diketahui oleh individu tersebut ketika hidup kecuali tumor ini telah memiliki ukuran yang signifikan besar.

Tumor ini terdapat pada dua individu, yaitu pada Rangka II yang terletak pada parietal kanan, dan pada Rangka III yang terletak pada parietal kiri. Tumor ini tidak mengganggu kedua indvidu ini ketika mereka masih hidup.

Presentase tercatatnya ivory osteoma pada konteks arkeologi, mencapai $41 \%$ dan pada konteks masa kini mencapai $38 \%$ dari populasi tanpa ada perbedaan pada ras, dan jenis kelamin (Eshed et al., 2002). Jika dibandingkan dengan perbandingan tersebut, sangat wajar untuk dapat menemukan osteoma tersebut pada populasi individu Caruban.

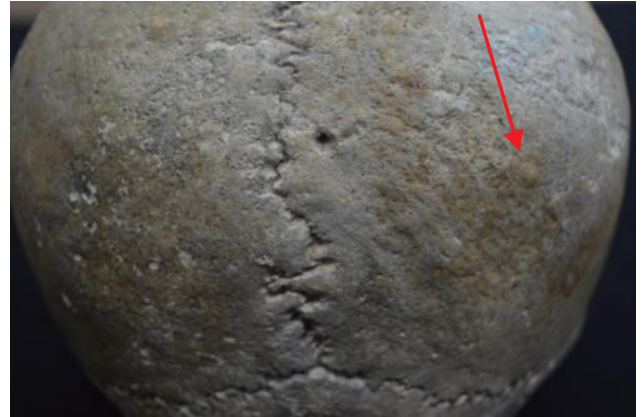

Gambar 7. Osteoma Pada Parietal Kanan Individu II

(Sumber: Dokumentasi Penulis)

\section{Trauma}

Pada rangka Caruban terdapat tanda-tanda trauma yang terjadi pada individu II. Pada bagian tulang sesamoid lateral metatarsal kiri pertama, tulang tersebut berukuran tiga kali dari ukuran normal. Letak tulang sesamoid pada kaki membuatnya menjadi rentan untuk terpengaruh oleh trauma dan fraktur (Nwawka et al., 2013: 582). Rangka II didiagnosis memiliki trauma yang berlanjut kepada sesamoiditis.

Terdapat lima penyakit yang umum terjadi pada tulang sesamoid yaitu, trauma, sesamoiditis, infeksi, osteoarthritis dan sindrom rasa sakit (Nwawka et al., 2013: 582). Pada Rangka II, kelainan yang terjadi merupakan trauma yang terjadi pada individu tersebut ketika masih muda. Dalam proses penggabungan kembali, tulang tersebut bersama dengan darah yang menggenang diantara otot kemudian membentuk osifikasi atau penulangan. Bentuk penulangan ini kemudian tidak berubah hingga individu ini meninggal. Pada tulang sesamoid Rangka II dapat dilihat alur yang merupakan pengikat jaringan otot flexor hallucis brevis.

Individu yang mengalami masalah ini akan merasakan rasa sakit seperti ditusuk dan pembengkakan, seringkali membuat 
individu ini menjadi pincang atau jalan dengan menggunakan bagian luar kakinya untuk menghindari rasa sakit. Keadaan ini dapat terjadi selama berbulan-bulan (Hubbard, 2005: 413; Nwawka et al., 2013: 583)

Pada kasus masa modern, cedera ini biasa terjadi pada orang yang sering meloncat, penari, pelari, atau orang yang sering menggunakan sepatu hak tinggi (Karasick \& Schweitzer, 1998: 416; Hubbard, 2005: 413). Jika dikaitkan dengan Rangka II, terdapat kemungkinan bahwa ketika hidup, individu ini berlari dan mendapatkan cedera pada telapak kakinya.

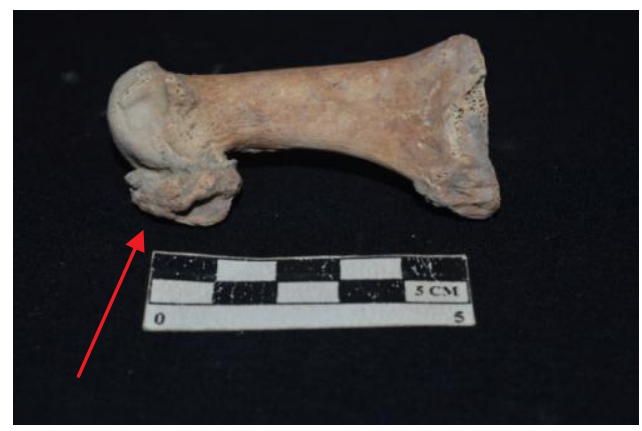

Gambar 8. Sesamoiditis Pada Individu II (Sumber: Dokumentasi Penulis)

\section{KONTEKS BUDAYA}

Selain penyakit dan kelainan fisik yang mempengaruhi rangkarangka Caruban tersebut, budaya juga mempengaruhi keberadaan rangka-rangka tersebut dan hal ini dapat diamati dari bentuk modifikasi gigi. Modifikasi gigi biasanya dilakukan sebagai penanda individu tersebut telah melakukan suatu ritus, kegiatan berkabung, identitas kelompok, konsep kecantikan, ritual pernikahan, atau tanda kedewasaan (Ichord, 2000: 84-85; Domett et al., 2011: 10-11).

Dental modifikasi dapat dibedakan menjadi empat bentuk, yaitu ablasi atau pencabutan gigi, filing atau pengikiran (pangur), pewarnaan, pengeboran gigi dan pengisian dengan material berhias (Barnes, 2010: 7-8).

Rangka Caruban mengalami dua jenis modifikasi gigi, yaitu pangur dan ablasi gigi. Mutilasi gigi dengan cara pengikiran (pangur) biasanya terjadi pada bagian gigi yang terlihat dari luar mulut individual tersebut, yaitu incisivus dan caninus.

Modifikasi gigi berbentuk pengikiran gigi atau pangur terdapat pada Rangka II. Proses modifikasi dilakukan pada bagian labial, lingual, dan occlusal gigi. Pada Rangka II juga dapat dirasakan pada permukaan occlusal gigi-gigi incisivus mandibula, bahwa individu ini mendapatkan proses pangur pada bagian occlusalnya dalam rentang waktu tidak lama sebelum individu ini meninggal hingga beberapa saat sebelum individu ini dikubur. Hal ini berdasarkan kepada bentuk occlusal yang kasar dan hampir tidak rata. Selain itu, jika diraba pada bagian occluso-lingual gigi-gigi incisivus, dapat dirasakan ketajaman yang merupakan bukti bahwa individu ini belum banyak menggunakan gigi incisivus setelah proses pangur hingga meninggal.

Selain itu terlihat bahwa modifikasi gigi terdapat pada gigi incisivus dan caninus maxilla. Incisivus pertama dan kedua maxilla kiri dan kanan mengalami modifikasi pada bagian labial dan lingual sehingga membuat gigi berbentuk datar meruncing. Pada rangka ini dapat dilinat bahwa proses pengerjaan modifikasi gigi dengan cara mengikir gigi dilakukan dari dua arah. Hal ini terlihat pada incisivus pertama maxilla kiri, di mana pada bagian lingual terdapat dua fasies. Modifikasi seperti ini terdapat pada situs lain, yaitu Semawang 
(Bali) dan Liang Toge (Flores) (Koesbardiati, et al, 2015: 54). Pada situs di Asia tenggara, proses pangur ditemukan pada individu dari situs seperti Phum Sophy dan Phum Snay, Kamboja. Pada situs Phum Sophy, modifikasi gigi dalam bentuk dental filing atau pengikiran gigi memiliki frekuensi yang sangat rendah dengan hanya $6,9 \%$ maxilla dan $4,3 \%$ mandibula yang memiliki bukti modifikasi. Sementara itu, Phum Snay mencapai 4,8\% untuk maxilla dan $6,5 \%$ untuk mandibula. Kesimpulan yang menarik dari penelitian tersebut adalah tidak ada kaitan antara umur, jenis kelamin dan modifikasi gigi (Domett et al., 2011: 4).

Terdapat bukti etnografi bahwa pangur masih dipergunakan hingga saat ini, seperti pada contohnya di Bali, dimana gigi diwarnai dan dipangur. Hal ini merupakan proses menuju dewasa untuk anak laki-laki dan perempuan yang biasanya dimulai setelah pubertas.

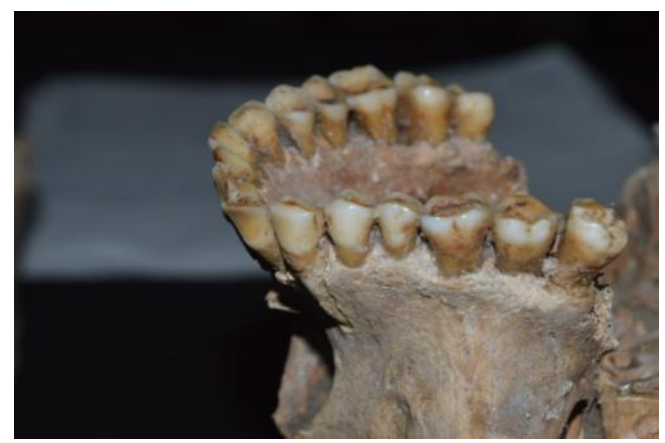

Gambar 9. Modifikasi Gigi Pada Bagian Labial dan Lingual Rangka II

(Sumber: Dokumentasi Penulis)

Selain dengan pangur, modifikasi gigi yang terdapat pada individu dari Caruban adalah pencabutan gigi atau ablasi gigi. Pada individu yang memiliki modifikasi ini, akan terlihat seperti gigi yang hilang sebelum meninggal (antemortem toothloss) dan dibedakan dengan posisinya yang simetris dan biasanya terjadi pada incisivus atau caninus.

Tanggalnya gigi-gigi pada Individu III terjadi pada gigi incisivus maxilla dan mandibula, sisi kiri dan kanan. Seluruh gigi incisivus memiliki tanda-tanda telah dicabut dan telah mengalami proses penyembuhan sehingga lubang alveolus telah tertutup.

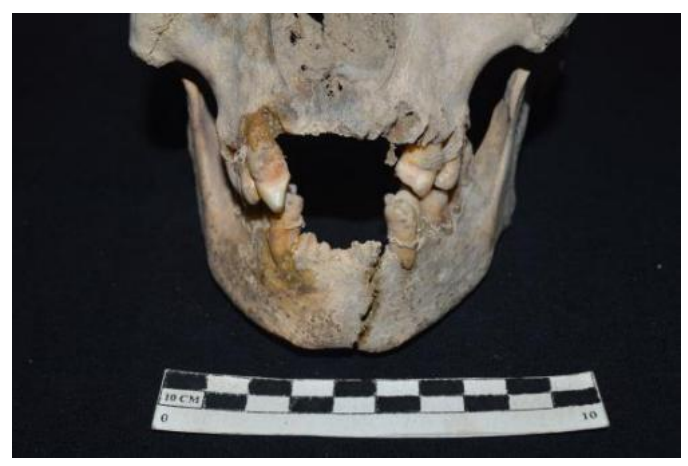

Gambar 10. Ablasi Gigi Pada Incisivus Individu III

(Sumber: Dokumentasi Penulis)

Tanggalnya gigi-gigi pada incisivus kiri dan kanan terdapat pada beberapa situs di Indonesia, yaitu Liang Bua, Lewoleba dan Melolo (Suriyanto \& Kosbardiati, 2010: 83). Pada konteks yang lebih luas, pencabutan gigi pada bagian incisivus dilaporkan terdapat pada kerangka dari situs masa Neolitik di Asia Tenggara, seperti Ban Kao di Thailand. Individu termuda yang mengalami proses ablasi berumur 18 tahun dan nampaknya menunjukkan bukti bahwa ablasi merupakan ritual menuju kedewasaan (Sangvichien et al., 1969: 33). Sementara itu, Situs Phum Snay and Phum Sophy, menunjukkan tingginya antemortem toothloss terjadi secara simetris $(83,5 \%$ pada maxilla dan $61,1 \%$ pada mandibula) (Domett et al., 2011: 3). Ablasi gigi yang dilakukan untuk alasan ritual nampak pada 
$72 \%$ individu dari situs Neolitik Khok Phanom Di (Thailand) dengan penanggalan 4000-3500 BP (Tayles, 1996: 335). Pada situs lainnya dari masa logam di Thailand, yaitu Noen U-Loke, terdapat individu yang kehilangan incisivus maxilla keduanya. Walaupun demikian, terdapat kemungkinan bahwa ketidakhadiran gigi incisivus maxilla lateral ini kemungkinan karena agenesis gigi, atau tidak munculnya gigi sejak lahir (Nelsen et al., 2001: 964).

\section{KESIMPULAN}

Berdasarkan analisis bioarkeologi pada rangka manusia dari Situs Caruban menunjukkan bahwa terdapat tiga individu dengan Rangka I memiliki jenis kelamin perempuan dengan umur ketika meninggal sekitar 15-16 tahun dan tinggi badan antara 154,69 - 156,99 $\mathrm{cm}$. Rangka II memiliki jenis kelamin laki-laki dengan umur ketika meninggal sekitar 40 tahun dan tinggi badan rata-rata $163-165 \mathrm{~cm}$. Sementara itu, Rangka III memiliki jenis kelamin perempuan dengan umur ketika meninggal sekitar 35-40 tahun.

Berdasarkan penelitian sebelumnya, individu-individu ini tergolong kepada ras Mongoloid dan pada pemeriksaan gigi-geligi menunjukkan kesimpulan yang sama dengan penelitian sebelumnya. Terdapat beberapa jenis penyakit yang dimiliki oleh individu-individu ini. Rangka I tidak terlihat adanya penyakit pada postcranium. Pada Rangka II terdapat osteopit pada patella, vertebra lumbalis dan vertebra cervicalis; terdapat karies; atrisi gigi; dan ivory osteoma pada parietal sebelah kanan. Sesamoiditis pada tarsal pertama menunjukkan bahwa individu ini pada masa muda kemungkinan besar cedera ketika berlari. Pada masa kini, hal tersebut sering terjadi pada pelari, penari balet, atau atlet profesional. Tinggi badan individu dan pelekatan otot pada tulang humerus, radius dan ulna yang sangat kentara mengesankan bahwa individu ini memiliki tubuh yang kekar. Pada Rangka III, penyakit dan kelainan yang terdapat pada individu ini adalah karies, kalkulus, atrisi, periodontitis, enamel hipoplasia, osteopit, ivory osteoma.

Sementara itu bukti pengaruh budaya terhadap rangka tersebut terlihat dari adanya mutilasi gigi pada Rangka II dan Rangka III. Pada Rangka II, mutilasi gigi terjadi pada gigi incisivus dan caninus dalam bentuk pangur, Sedangkan pada Rangka III terdapat ritual pencabutan gigi incisivus pertama dan kedua pada mandibula dan maxilla kiri dan kanan.

Hasil dari penelitian ini diharapkan dapat memberikan tambahan data untuk penelitian lebih lanjut mengenai penyakit pada masa lampau di Indonesia, dan penelitian dengan konteks yang lebih luas di Asia Tenggara, terutama penelitian mengenai modifikasi gigi dan kaitannya dengan situs-situs lain di Asia tenggara. 


\section{DAFTAR PUSTAKA}

Barnes, D.M. 2010. Dental modification: an anthropological perspective. University of Tennessee: Honor thesis projects. Available: http://trace.tennessee.edu/utk_chanhonoproj/1345.

Bergman, R.A.M. and The, T.H. 1955. "The length of the body and long bones of the Javanese". In Documenta de Medecina Geographica et Tropica, 7, 197214.

Boedhisampurno, S. 1984. "Kerangka manusia dari Caruban, Lasem, Jawa Tengah". Rapat Evaluasi Hasil Penelitian Arkeologi II.

Buikstra, J.E., and D.H. Ubelaker. 1994. Standards for Data Collection from Human Skeletal Remains. Fayetteville: Arkansas Archaeological Survey.

Bulbeck, F.D. 2005. "The guar kepah human remains". In The Perak man and other prehistoric skeletons of Malaysia, 384-423. Edited by Zuraina Majid. Pulau Pinang: Universiti Sains Malaysia.

Cekalovic, H. 2014. Health and society in Southeast Asia: the transition from the late Bronze age to Iron age. PhD thesis, James Cook University.

Domett, K.M., and Buckley, H.R. "Large lytic cranial lesions: $S$ differential diagnosis from pre-Angkorian Cambodia". International Journal of Osteoarchaeology, 22 (2012): 731-739.

Domett, K.M., Newton, J., O'Reilly, D.W.J., Tayles, N., Shewan, L., and Beavan, N. "Cultural modification of the dentition in prehistoric Cambodia". International Journal of Osteoarchaeology 23 (3) (2011): 274-286.

Douglas, M.T. 1996. Paleopathology in human skeletal remains from pre-metal Bronze and Iron ages, Northeast Thailand. PhD Thesis. University of Hawaii, Hawaii.

Eshed, V., Latimer, B., Greenwald, C.M., Jellema, L.M., Rothschild, B.M., WishBaratz, S., and Hershkovitz, I. Button osteoma: its etiology and pathophysiology. American Journal of Physical Anthropology 118 (2002): 303-315.

Hillson, S. 1996. Dental Anthropology. Cambridge: Cambridge University Press. 
Hubbard, C.E. 2005. "The foot and ankle". In Sports Medicine: A Comprehensive Approach. 405-418. Edited by Scuderi, G.R. and McCann, P.D. Philadelphia: Elsevier.

Ichord, L.F. 2000. Toothworms and spider juice: an illustrated history of dentistry. Brookfield: Millbrook press.

Immel, A., et al. 2016. "Effect of X-ray radiation on ancient DNA in sub-fossil bones-Guidelines for safe X-ray imaging". Sci Rep, 6: 1-14. DOI: 10.1038/srep32969. Diunggah 12 September 2016.

Indriati, E. 2006. "Cranial lesion on the late Pleistocene Indonesian Homo erectus Ngandong 7". In Bioarchaeology of Southeast Asia, 290-308. Edited by Oxenham, M and Tayles, N. Cambridge: Cambridge University Press.

Karasick, D., Schweitzer, M.E. "Disorders of the hallux sesamoid complex: MR features". Skeletal Radiology 27 (1998): 411-418.

Koesbardiati, T., Murti, D.B., Suriyanto, R.A. "Cultural dental modification in prehisotric population in Indonesia". Bull Int Assoc Paleodont. 9 (2) (2015): 52-60.

Labidon, S.L.S. 2012. Health in the late pre-colonial and early colonial period in the Philippines. Master thesis, University of Otago.

Latham, K. J. "Human health and the Neolithic revolution: an overview of impacts of the agricultural transition on oral health, epidemiology, and the human body". Nebraska Anthropologist 187 (2013): 95-102.

Lovejoy, C.O. "Dental wear in the Libben population: Its functional pattern and role in the determination of adult skeletal age at death". American Journal Physical Anthropology 68 (1) (1985): 47-56.

Lovejoy, C.O., Meindl, R.S., Pryzbeck, T.R., and Mensforth, R.P. "Chronological Metamorphosis of the Auricular Surface of the llium: A New Method for the Determination of Adult Skeletal Age at Death". American Journal of Physical Anthropology 68 (1985): 15-28.

McDonell, A. and Oxenham, M.F. "Localised primary caninus hypoplasia: Improcations for maternal and infant health at Man Bac, Vietnam, 40003500 years B.P”. International Journal of Osteoarchaeology 24 (2014): 531 539. 
Meindl, R.S. and C.O. Lovejoy. "Ectocranial Suture Closure: A Revised Method for the Determination of Skeletal Age at Death Based on the Lateral Anterior Sutures". American Journal of Physical Anthropology 68 (1985): 57-66.

Nastiti, T.S., dan Rangkuti, N. 1988. Laporan penelitian ekskavasi caruban, Lasem, Jawa Tengah. Berita Penelitian Arkeologi No. 38. Jakarta: Departemen Pendidikan dan Kebudayaan.

Nelsen, K., Tayles, N., Domett, K. "Missing lateral incisors in Iron age Southeast Asians as possible indicators of dental agenesis". Archives of Oral Biology 46 (2001): 963-971.

Newton, J.S., Domett, K.M., O`Reilly, D.J.W., and Shewan, L. "Dental health in Iron Age Cambodia: Temporal variations with rice agriculture". International Journal of Paleopathology 3 (1) (2013):1-10.

Noerwidi, S. "Aspek biokultural sisa rangka manusia dari Situs Liangan, Temanggung, Jawa Tengah”. Berkala Arkeologi Vol. 36 No. 1 (2016): 8398.

Nwawka, O.K., Hayashi, D., Diaz, L.E., Goud, A.R., Arndt III, W.F., Roemer, F.W., Malguria, N., Guermazi, A. Sesamoids and accessory ossicles of the foot: anatomical variability and related pathology. Insight Imaging 4 (5) (2013): 581-591.

Oxenham, M.F., Nguyen, L.C., and Nguyen, K.T. 2006. "The oral health consequences and intensification of agriculture in Southeast Asia". In Bioarchaeology of Southeast Asia, 263-289. Edited by Oxenham, M.F. and Tayles, N. Cambridge: Cambridge University Press.

Ortner, D.J. 2003. Identification of pathological conditions in human skeletal remains. San Diego: Academic Press.

Pietrusewsky, M., and Douglas, M.T. "Intensification of Agriculture at Ban Chiang: is there evidence from the skeletons?". Asian Perspectives 40 (2001): 157178.

Pinhasi, R., Eshed, V., von Crammon Taubadel, N. 2015. "Incongruity between affinity patterns based on mandibular and lower dental dimensions following the transition to agriculture in the Near East, Anatolia and Europe". PLOS ONE 10(2): e0117301. Doi: 10.1371/journal.pone.0117301. Diunggah 4 Februari 2015. 
Prijoharijono, M.R. 1986. Penerapan sampling pada situs Caruban, Lasem. Pertemuan IImiah Arkeologi IV.

Rangkuti, N. 1986. Analisis pola artefak situs permukiman di Caruban, Lasem. Pertemuan IImiah Arkeologi IV.

Regezi, J., Sciubba, J., and Pogrel, M. 2000. Atlas of oral and maxillofacial pathology. Philadelphia: Saunders.

Roberts, C.A. and Manchester, K. 2005. The archaeology of disease. Glouchestershire: Sutton Publishing.

Sangvichien, S., Sirigaroon, P., Jorgensen, J.B., Jacob, T. 1969. Archaeological excavations in Thailand Volume III: Ban-Kao. Part 2: The prehistoric Thai Skeletons. Copenhagen: Minksgaard.

Satari, S.S. 1985. Caruban, lasem: Suatu situs peralihan klasik-Islam. Pertemuan IImiah Arkeologi III, Ciloto.

Sheiham, A. Dental caries affects body weight, growth, and quality of life in preschool children. British Dental Journal 201 (2006): 625-626.

Snell, C.A.R.D. Human skeletal remains from Gol Ba'it, Sungai Siput, Perak, malay Peninsula. Acta neerlandica Morphologica Normalis et Pathologicae 6 (1949): 353-377

Sukadana, A.A., and Wangania, S.E. 1977. Beberapa hasil penelitian sisa-sisa kerangka manusia di Jawa Timur. Proyek rehabilitasi dan perluasan museum Jawa Timur.

Suriyanto, R.A. and Koesbardiati, T. Dental modifications: a perspective of Indonesian chronology and the current applications. Dental Journal (Majalah Kedokteran Gigi) 43 (2) (2010): 81-90.

Tayles, N. "Tooth ablation in prehistoric Southeast Asia". International Journal of Osteoarchaeology 6 (1996): 333-345.

Tayles, N. "Murder or mortuary behaviour? An Iron age enigma from Northeast Thailand". International Journal of Osteoarchaeology 13 (2003): 197-206.

Tayles, N., Domett, K., and Nelsen, K. "Agriculture and dental caries? The case of rice in prehistoric Southeast Asia". World Archaeology 32 (1) (2000): 6883. 
Todd, T. W. (1920) "Age changes in the pubic bone. I. The male white pubis". American Journal Physical Anthropology 3: 285-334. doi:10.1002/ajpa.1330030301

Trotter, M. and Gleser, G. C. 1958. A re-evaluation of estimation of stature based on measurements of stature taken during life and of long bones after death. American Journal of Physical Anthropology, 16: 79-123. doi:10.1002/ajpa.1330160106

Vlok, M., Paz, V., Crozier, R., and Oxenham, M. (2017). "A new application of the Bioarchaeology of care approach: A case study from the Metal period, Philippines". International Journal of Osteoarchaeology. doi: 10.1002/002588.

White, T. D., and Pieter Arend Folkens. 2005. The Human Bone Manual. Burlington: Elsevier.

Willis, A., and Oxenham, M.F. "A case of maternal and perinatal death in Neolithic Southern Vietnam, c. 2100-1050 BCE”. International Journal of Osteoarchaeology 23 (2013): 676-684.

Willman, J.C., Shackelford, L., and Demeter, F. "Incisivus ablation among the late upper paleolithic people of Tam Hang (Northern Laos): Social identity, mortuary practice, and oral health". American Journal of Physical Anthropology 160 (2016): 519-528 


\section{LAMPIRAN}

Tabel 1. Penyakit gigi-geligi pada rangka II

\begin{tabular}{|l|l|l|l|l|l|l|l|l|l|l|l|l|l|l|l|}
\hline \multicolumn{10}{|c|}{ Kanan } & \multicolumn{10}{c|}{ Kiri } \\
\hline & & & & & & & & & & & & & Cal & Cal & \\
\hline & & & & & M & M & M+ & M+ & M & M & & & Per & & \\
\hline 8 & 7 & 6 & 5 & 4 & 3 & 2 & 1 & 1 & 2 & 3 & 4 & 5 & 6 & 7 & 8 \\
\hline & Co & C & & & CR & E & & M & M & & & & & Co & Co \\
\hline & & & Cal & Cal & Cal & Cal & Cal & Cal & Cal & Cal & Cal & & Cal & Cal & Cal \\
\hline
\end{tabular}

Tabel 2. Penyakit gigi-geligi pada rangka III

\begin{tabular}{|l|l|l|l|l|l|l|l|l|l|l|l|l|l|l|l|}
\hline \multicolumn{10}{|c|}{ Kanan } & \multicolumn{10}{|c|}{ Kiri } \\
\hline & & & & & M+ & & & & & & & & & & \\
\hline & & Cal & Cal & & E & & & & & & & Cal & Cal & & \\
\hline & Cal- & Cal- & Cal- & Cal- & Cal- & A & A & A & A & PM & PM & Cal- & Cal- & PM & PM \\
\hline $\mathbf{8}$ & $\mathbf{7}$ & $\mathbf{6}$ & $\mathbf{5}$ & $\mathbf{4}$ & $\mathbf{3}$ & $\mathbf{2}$ & $\mathbf{1}$ & $\mathbf{1}$ & $\mathbf{2}$ & $\mathbf{3}$ & $\mathbf{4}$ & $\mathbf{5}$ & $\mathbf{6}$ & $\mathbf{7}$ & $\mathbf{8}$ \\
\hline U & Cal- & Cal- & Cal- & Cal- & PM & A & A & A & A & PM & Cal- & Cal- & Cal- & Cal- & Cal- \\
\hline & Cro & & & & & & & & & & & & & Cro & Cro \\
\hline & & & & & & & & & & & & & & & Per \\
\hline
\end{tabular}

Keterangan:

C : Karies

Per : Periodontitis

CW : Dental crowding

E : Enamel hipoplasia

M : Modifikasi gigi hanya pada labial dan/atau occlusal

$\mathrm{M}+\quad$ : Modifikasi gigi yang terdapat pada lingual

Co : Karies pada occlusal

Cro : Karies pada akar gigi

Cal-` : Kalkulus gigi sub-gingival

Cal : Kalkulus gigi supra-gingival

$\mathrm{U} \quad$ : Molar yang belum erupsi

A : Antemortem toothloss (Ablasi gigi)

PM : Postmortem toothloss 


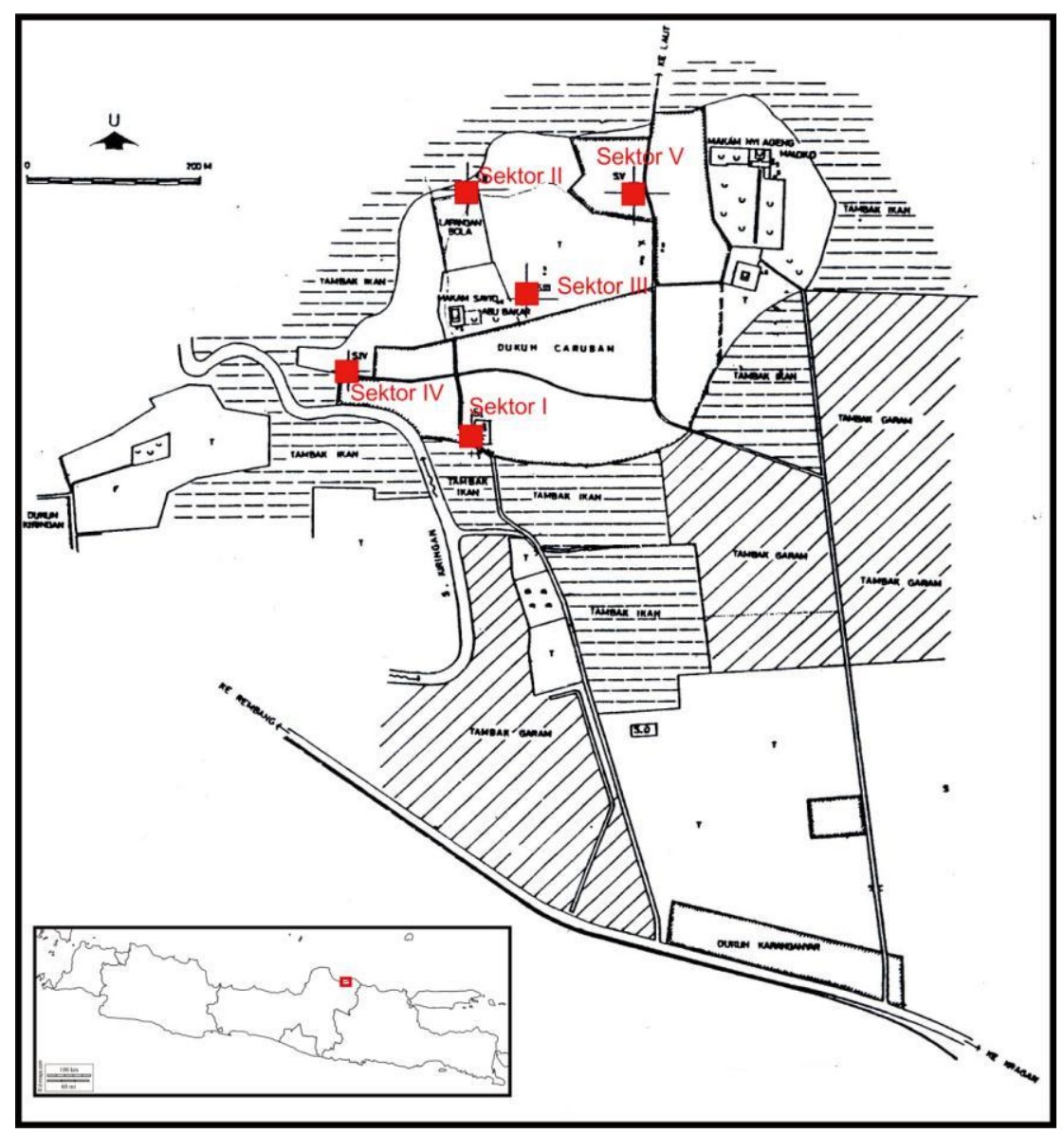

Peta 1. Peta Lokasi Situs Caruban

(Sumber: Nastiti dan Rangkuti, 1988: 80) 
Penyakit Masa Lampau Pada Penduduk Caruban Masa Klasik-Islam: 